\title{
Learning from the Chronic Disease Model in Treating Addiction
}

\author{
Melinda Drake* \\ Santa Monica College, USA
}

Submission: May 14, 2017; Published: May 24, 2017

*Corresponding author: Melinda Drake, Santa Monica College, 1900 Pico Blvd, Santa Monica, California, 90405, USA, Tel: 8033310865; Email: mggdrake@gmail.com

Abbreviations: ASAM: American Society of Addiction Medicine; CDC: Center for Disease Control and Prevention; MAT: Medication Assisted Treatment; CARA: Comprehensive Addiction and Recovery Act; CCM: Chronic Care Model; ICIC: Improving Chronic Illness Care; ICCC: Innovative Care for Chronic Conditions; SM: Stanford Model; CBTM: Community based Transition Model; DATA: Drug Addiction Treatment Act

\section{Opinion}

Addiction was redefined by the American Society of Addiction Medicine (ASAM) as a primary, chronic disease of brain reward, motivation, memory and related circuitry in 2012 [1]. But it has yet to be treated like other chronic diseases. Even the CDC Chronic Disease Overview webpage does not list addiction as a chronic disease. In the United States, according to the Center for Disease Control and Prevention (CDC), chronic disease is the major cause of death and disability (2016). In 2015, addiction became the leading cause of accidental death in the US, with 52,404 lethal drug overdoses [2].

Treatment modality debates in addiction seem to also overlook lessons from the chronic disease treatment model, that the life of a patient afflicted with a chronic disease is irreversibly changed. Like any chronic disease, addiction and its consequences in a patient's life create a continuous relapsing pattern when it is not managed. Medication alone for chronic diseases such as heart disease, cancer, stroke, chronic obstructive pulmonary disease, and diabetes was not enough, yet Medication Assisted Treatment (MAT) has been pushed by insurance and governmental entities to address the opiate epidemic through the Drug Addiction Treatment Act of 2000 (DATA 2000) and the Comprehensive Addiction and Recovery Act (CARA) in 2016 [3].

There are five chronic disease models currently used in the US. Chronic Care Model (CCM), Improving Chronic Illness Care (ICIC), and Innovative Care for Chronic Conditions (ICCC), Stanford Model (SM) and Community based Transition Model (CBTM). CCM is the most studied. A meta-analysis of chronic disease models by Grover and Joshi [4] found that management of chronic disease requires that patients take a more active role in the day-to-day decisions about the management of their illness. They found that CCM addressed the problem with the current care being"reactive and triggered by actual problems instead of being proactive, structured and planned." Addiction requires the same proactive, structured and planned approach in dealing with the inevitability of relapses occurring. Relapses should be not be treated as a failure of treatment, but as a condition associated with the chronic nature of addiction.

Applying the chronic disease model paradigm in addressing addiction involves integration of care: aprimary contact, which could be the patient's primary care physician or therapist, to manage care. This primary contact should belong term and consistent relationship over time. The care should be comprehensive with coordination involving primary care systems to coordinate care across providers, ideally using electronic information systems. The primary contact should be responsible for patient's overall treatment outcomes. The current treatment system is fragmented. Seldom do we find primary care physician addressing and/or coordinating addiction care for their patients. Conversely, patients tend to not have continuity in treatment between the addiction treatment provider and the primary care physician. When a therapist is involved, there seems to be a higher probability of involvement, coordination and continuity with the addiction treatment provider, though integration is still lacking.

Bodenheimer et al. [3] reported that patients with chronic conditions must manage their illness. For patients to have the best quality of life with their chronic condition, they would need 
to self-manage and learn new behaviors. A patient afflicted with addiction would need to learn new behaviors to support recovery. The concept of self-management education for chronic conditions can be applied to addiction. Recovery from addiction requires the same self-management education for problemsolving and self-efficacy skills. The chronic disease model of a working patient-provider partnership which involves effective treatment within an integrated system of collaborative care and self-management education is needed to address addiction as a chronic disease.

\section{References}

1. (2017) American Society of Addiction Medicine (2011, April 19).

2. American Society of Addiction Medicine (nd). Opiate Addiction 2016 Facts \& Figures [Brochure].

3. Bodenheimer T, Lorig K, Holman H, Grumbach K (2002) Patient Selfmanagement of Chronic Disease in Primary Care. JAMA 288(19): 24692475.

4. Grover A, Joshi A (2015) An Overview of Chronic Disease Models: A Systematic Literature Review. Global Journal of Health Science 7(2): 210-227.

Your next submission with Juniper Publishers will reach you the below assets

- Quality Editorial service

- Swift Peer Review

- Reprints availability

- E-prints Service

- Manuscript Podcast for convenient understanding

- Global attainment for your research

- Manuscript accessibility in different formats ( Pdf, E-pub, Full Text, Audio)

- Unceasing customer service

Track the below URL for one-step submission https://juniperpublishers.com/online-submission.php 